\title{
Antimicrobial potential of a bioactive coating based on chitosan incorporated with clove essential oil in hamburger-like meat product
}

\author{
Potencial antimicrobiano de revestimento bioativo a base de quitosana incorporado com óleo \\ essencial de cravo-da-índia em produto cárneo análogo a hambúrguer \\ Potencial antimicrobiano del recubrimiento bioactivo a base de quitosano incorporado com aceite \\ essencial de clavo em um produto cármico similar a uma hamburguesa
}

Received: 08/12/2021 | Reviewed: 08/18/2021 | Accept: 08/21/2021 | Published: 08/23/2021

Pâmela Inchauspe Corrêa Alves

ORCID: https://orcid.org/0000-0002-8229-9602 Federal University of Pelotas, Brazil

E-mail: pam.inchauspe@hotmail.com

Marjana Radünz

ORCID: https://orcid.org/0000-0002-5160-3050 Federal University of Pelotas, Brazil E-mail: marjanaradunz@gmail.com

Caroline Dellinghausen Borges

ORCID: https://orcid.org/0000-0002-8467-3418

Federal University of Pelotas, Brazil

E-mail: caroldellin@hotmail.com

Caroline Peixoto Bastos

ORCID: https://orcid.org/0000-0003-2985-423X

Federal University of Pelotas, Brazil

E-mail: carolpebastos@yahoo.com.br

Cláudio Dias Timm

ORCID: https://orcid.org/0000-0003-3920-9066 Federal University of Pelotas, Brazil E-mail: timm@ufpel.com

Eliezer Avila Gandra

ORCID: https://orcid.org/0000-0003-0978-6014 Federal University of Pelotas, Brazil

E-mail: gandraea@hotmail.com

\begin{abstract}
The food industry is looking for strategies to prevent microbial growth in order to ensure food safety and shelf life. However, the use of synthetic preservatives, such as nitrate and nitrite in meat products, entails risks to human health. An alternative is the utilization of essential oils, widely known for their antimicrobial properties. This work aimed the antimicrobial potential of a bioactive coating based on chitosan incorporated with clove essential oil in in hamburgerlike meat product. Through the analysis of antimicrobial activity by diffusion in agar and broth, there was an action against Gram-positive and Gram-negative bacteria. Regarding Staphylococcus aureus and Escherichia coli, the minimum inhibitory concentration (MIC) was $3.74 \mathrm{mg} / \mathrm{mL}$ and the minimum bactericidal concentration (MBC) was $374.33 \mathrm{mg} / \mathrm{mL}$ for both. In the micro atmospheric diffusion test, CEO reduced by up to 70 and $76 \%$ of the E. coli and S. aureus bacteria development, respectively. CEO was applied as an active component in chitosan-based coatings in hamburger-like meat, in which it was able to promote the control of microbial proliferation of Total Coliforms, Coliforms at $45{ }^{\circ} \mathrm{C}$ and Coagulase-Positive Staphylococcus throughout 7 days of storage under refrigeration. It is concluded that the bioactive coating based on chitosan incorporated with clove essential oil promotes microbiological control in hamburger-like meat product.
\end{abstract}

Keywords: Syzygium aromaticum; Antimicrobial activity; Bioconservative; Hamburger; Eugenol.

\section{Resumo}

A indústria alimentícia busca por estratégias que previnam o crescimento microbiano, a fim de garantir a segurança e a vida útil dos alimentos. No entanto, o uso de conservantes sintéticos, como nitrato e nitrito em produtos cárneos, acarreta riscos à saúde humana. Uma alternativa é a utilização de óleos essenciais, os quais são amplamente conhecidos por suas propriedades antimicrobianas. Este trabalho teve como objetivo avaliar o potencial antimicrobiano de um revestimento bioativo à base de quitosana incorporado ao óleo essencial de cravo-da-índia em um produto cárneo análogo a hambúrguer. Por meio da análise da atividade antimicrobiana por difusão em ágar e 
caldo, houve ação contra bactérias Gram-positivas e Gram-negativas. Em relação a Staphylococcus aureus e Escherichia coli, a concentração inibitória mínima (CIM) foi de 3,74 mg/mL e a concentração bactericida mínima (CBM) foi de $374,33 \mathrm{mg} / \mathrm{mL}$ para ambos. No teste de difusão em micro-atmosfera, o óleo essencial de cravo-da-índia (OEC) reduziu em até 70 e $76 \%$ o desenvolvimento das bactérias E. coli e $S$. aureus, respectivamente. O OEC foi aplicado como um componente ativo em revestimentos à base de quitosana em produto carne análogo a hambúrguer, no qual foi capaz de promover o controle da proliferação microbiana de Coliformes Totais, Coliformes a $45{ }^{\circ} \mathrm{C}$ e Staphylococcus Coagulase-Positivo ao longo de 7 dias de armazenamento sob refrigeração. Conclui-se que o revestimento bioativo à base de quitosana incorporado ao óleo essencial de cravo-da-índia promove o controle microbiológico em produtos cárneos do tipo hambúrguer.

Palavras-chave: Syzygium aromaticum; Atividade antimicrobiana; Bioconservante; Hambúrguer; Eugenol.

\section{Resumen}

La industria alimentaria busca estrategias que eviten el crecimiento microbiano para garantizar la seguridad y la vida útil de los alimentos. Sin embargo, el uso de conservantes sintéticos como el nitrato y el nitrito en productos cárnicos presenta riesgos para la salud humana. Una alternativa es utilizar aceites esenciales, que son ampliamente conocidos por sus propiedades antimicrobianas. Este trabajo tuvo como objetivo evaluar el potencial antimicrobiano de un recubrimiento bioactivo a base de quitosano incorporado al aceite esencial de clavo en un producto cárnico análogo a la hamburguesa. Al analizar la actividad antimicrobiana por difusión en agar y caldo, se encontró acción frente a bacterias Gram positivas y Gram negativas. En cuanto a Staphylococcus aureus y Escherichia coli, la concentración mínima inhibitoria (MIC) fue de 3,74 mg/mL y la concentración bactericida mínima (CBM) fue de $374,33 \mathrm{mg} / \mathrm{mL}$ para ambos. En la prueba de difusión en micro-atmósfera, el aceite esencial de clavo (AEC) redujo el desarrollo de las bacterias E. coli y $S$. aureus hasta en un 70 y 76\%, respectivamente. AEC se aplicó como componente activo en recubrimientos a base de quitosano en un producto cárnico similar a una hamburguesa, que pudo controlar la proliferación microbiana de Coliformes Totales, Coliformes a $45{ }^{\circ} \mathrm{C}$ y Estafilococos Coagulasa Positivos durante 7 días de almacenamiento refrigerado. Se concluye que el recubrimiento bioactivo a base de quitosano incorporado al aceite esencial de clavo promueve el control microbiológico en productos cárnicos tipo hamburguesa.

Palabras clave: Syzygium aromaticum; Actividad antimicrobiana; Bioconservante; Hamburguesa; Eugenol.

\section{Introduction}

The industry implements different conservation methods during the production and marketing of products of animal origin, in order to delay or prevent microbiological, chemical or physical changes that male them unfit for human consumption (Macwan etal. 2016). However, food safety issues are one of the main concerns associated with public health, since outbreaks of foodborne diseases are annually recorded worldwide (Burt, 2004; Macwan et al., 2016).

Allied with this fact, the addition of synthetic preservatives to foods is confronted with the increase in consumer demand for products of natural origin (Calo et al., 2015). Such preservatives can cause complications to human health, such as the use of nitrate, nitrite and their respective salts of sodium $(\mathrm{Na})$ and potassium $(\mathrm{K})$, which have a carcinogenic potential when consumed excessively (Sindelar \& Milkowski, 2011; World Health Organization, 2015).

Essential oils are among the alternatives with the potential to replace synthetic preservatives in meat products, either partially or totally. These compounds are derived from the specialized metabolism of aromatic plants. Plants trigger natural defense mechanisms against edaphoclimatic and pathogenic factors, synthesizing biologically active molecules, such as terpenes and phenolic compounds, through their specialized metabolism, providing essential oils with an antimicrobial capacity (Burt, 2004).

The clove essential oil (Syzygium aromaticum L.) has demonstrated prominent antimicrobial activity against important foodborne pathogenic bacteria (Radünz et al., 2019; Ghabraie et al., 2016; Hosseini et al., 2015; Scopel et al., 2014). Meanwhile, the direct application of essential oils to the food matrix can cause undesirable sensory interferences, due to the characteristic odors and flavors (Dannenberg et al., 2016; Otoni et al., 2016).

Nonetheless, this limitation can be reduced with the implementation of essential oil in edible coatings, avoiding its direct incorporation into the food and, thus, concentrating its action on the food surface, where microbial contamination is 
more intense (Appendini \& Hotchkiss, 2002; Coma, 2008). In addition, the volatility and instability of essential oil under environmental conditions, such as temperature, light, and oxygen, can be reduced (Radünz et al., 2019).

Among the coating options, there is chitosan, a polysaccharide derived from chitin, which is a component synthesized by a variety of living organisms (Kurita, 2006). Chitosan is used in the preparation of coatings as a natural and non-toxic product, capable of forming films with antimicrobial properties (Gómez-Estaca et al., 2010).

In view of the potentiality of clove essential oil as an antimicrobial in foods, the objective of the present study was to assess its antimicrobial activity against Staphylococcus aureus and Escherichia coli and evaluate the effect of edible coatings based on chitosan incorporated with clove essential oil on the microbiological characteristics in a hamburger-like meat product.

\section{Methodology}

\section{Extraction and characterization of essential oils}

Samples of dried clove flower buds were purchased from local businesses in the city of Pelotas, RS. The clove essential oils were extracted according to methods described in the Brazilian Pharmacopeia (Brazil, 2010) by hydrodistillation for 3 h using a Clevenger apparatus (Vidrolabor, Brazil).

Clove essential oil compounds were evaluated by gas chromatography. A $1 \mu \mathrm{L}$ sample of essential oil was diluted with 1:20 (v:v) n-hexane and injected into a gas chromatograph coupled with a mass spectrophotometer GCMS-QP2010 Ultra (Shimadzu ${ }^{\mathrm{TM}}$, Kyoto, Japan) with an automatic injector AOC20i (Shimadzu ${ }^{\mathrm{TM}}$, Kyoto, Japan) and a capillary column OV-5MS $(30 \mathrm{~m} \times 0,25 \mathrm{~mm} \times 0,25 \mu \mathrm{m})$.

The elution gradient started at $60^{\circ} \mathrm{C}$ for $1 \mathrm{~min}$ in isothermal mode followed by heating to $180^{\circ} \mathrm{C}$ at a rate of $5^{\circ} \mathrm{C} / \mathrm{min}$, remaining at $180{ }^{\circ} \mathrm{C}$ for $1 \mathrm{~min}$ in isothermal mode, followed by heating to $280^{\circ} \mathrm{C}$ at a rate of $40^{\circ} \mathrm{C} / \mathrm{min}$, remaining at $280{ }^{\circ} \mathrm{C}$ for $1.5 \mathrm{~min}$ in isothermal mode, for a $30 \mathrm{~min}$ total run time. The injection temperature was $200^{\circ} \mathrm{C}$ with a flow rate of $1 \mathrm{~mL} / \mathrm{min}$ using split mode helium gas (ratio 50:1). The sweep range was 40 to $450 \mathrm{~m} / \mathrm{z}$ with the solvent cut in $3 \mathrm{~min}$. The interphase temperature was $270{ }^{\circ} \mathrm{C}$, and the ion source temperature was $260{ }^{\circ} \mathrm{C}$. The mass spectrometer was operated with $70 \mathrm{eV}$ electronic impact ionization.

Identification of compounds was based on comparison of mass spectra with the NIST11 library (Mass Spectra Library, USA). Concentrations were presented as percentages of area under each peak relative to total area.

\section{Microorganisms}

For the determination of the antimicrobial potential in vitro, two microorganisms were used, one Gram-positive bacteria: Staphylococcus aureus (ATCC 10832) and one Gram-negative: Escherichia coli O157:H7 (ATCC 43895).

The analyses for enumeration of Total Coliforms, Coliforms at $45{ }^{\circ} \mathrm{C}$ (Thermotolerants) and Coagulase-Positive Staphylococcus in a hamburger-like meat product were performed according to the procedures proposed by the American Public Health Association (APHA) with modifications (Downes \& Ito, 2001).

\section{Disk diffusion}

Initially, the CEO antimicrobial activity was determined by the disk diffusion technique (CLSI, 2012). The bacterial cultures were suspended in saline $\mathrm{NaCl}(0.85 \%)$, obtaining a concentration of $1.5 \times 10^{8} \log \mathrm{CFU} \mathrm{mL} \mathrm{m}^{-1}(0.5 \mathrm{McFarland})$. In the technique, three small equidistant disks (diameter $5 \mathrm{~mm}$ ) were made with a sterile aluminum cylinder in the center of the Petri dishes containing Mueller-Hinton agar $\left(\mathrm{Oxoid}^{\circledR}\right)$. The cell suspension was inoculated on the agar surface with the aid of a sterile swab, and $10 \mu \mathrm{L}$ of essential oil was added to each disk. As a negative control, $10 \mu \mathrm{L}$ of sterile distilled water was used. 
The plates were incubated at $37^{\circ} \mathrm{C}$ and the readings were taken after $24 \mathrm{~h}$ of incubation, in which the existence of inhibition halos was analyzed, quantifying the existing ones with calipers, expressing them in millimeters.

\section{Minimum Inhibitory Concentration and Minimum Bactericidal Concentration}

The Minimum Inhibitory Concentration (MIC) and Minimum Bactericidal Concentration (MBC) were performed using the methods described by Cabral et al. (2009) with modifications. CEO was tested in four different concentrations: $374.33 \mathrm{mg} / \mathrm{mL}, 74.86 \mathrm{mg} / \mathrm{mL}, 37.43 \mathrm{mg} / \mathrm{mL}$ and $3.74 \mathrm{mg} / \mathrm{mL}$. Microbial growth was assessed by turbidity readings at a wavelength of $620 \mathrm{~nm}$ employing a spectrophotometer (Biochrom EZ Read 400) at the time of preparation and after $24 \mathrm{~h}$ of incubation. MIC was considered the lowest concentration of essential oil that prevents bacterial growth in the culture medium.

To detect MBC, $15 \mu \mathrm{L}$ aliquots from each well, with inhibition in the MIC test, were inoculated in Petri dishes containing Brain Heart Infusion agar $\left(\mathrm{KASVI}^{\circledR}\right)$. The lowest concentration without growth in this new medium was considered MBC.

\section{Antimicrobial activity in micro-atmosphere}

The antimicrobial activity in the micro atmosphere was evaluated using the technique proposed by Ghabraie et al. (2016) with modifications. Aliquots of $0.1 \mathrm{~mL}$ of the bacteria cell suspensions $\left(10^{8} \log \mathrm{UFC}^{\mathrm{mL}} \mathrm{m}^{1}\right)$ were inoculated by implementing the technique of spreading BHI agar (KASVI $\left.{ }^{\circledR}\right)$ on the surface of Petri dishes. Sterile filter paper discs (15 mm) were placed on the lid of each plate, in which different volumes of CEO (100, 50, 25 and $12.5 \mu \mathrm{L})$ were added and immediately closed and sealed with parafilm film, with inverted (coating down) incubation at $37{ }^{\circ} \mathrm{C}$ for $24 \mathrm{~h}$. The antimicrobial action was expressed by the cell count (CFU) percentage reduction of treatments with essential oil compared to a control containing sterile distilled water.

\section{Preparation of chitosan coating}

The chitosan coating was prepared according to the methodology proposed by Moradi et al. (2011) with modifications. The chitosan solution was formulated by dissolving $2 \mathrm{~g}$ of chitosan in $100 \mathrm{~mL}$ of glacial acetic acid (1\% $\left.\mathrm{SYNTH}^{\circledR}\right)$ under magnetic stirring overnight. Then, $1 \mathrm{~mL}$ of glycerin $\left(1 \%-\mathrm{SYNTH}^{\circledR}\right)$ and $0.1 \mathrm{~mL}$ of Tween $80(0.1 \%$ $\mathrm{SYNTH}^{\circledR}$ ) were added to the solution. CEO was added to the solution at a concentration of $1 \%(\mathrm{v} / \mathrm{v})$. The mixtures were homogenized in Ultra-Turrax (Metabo) at 27,000 rpm for $20 \mathrm{~min}$.

\section{Antimicrobial activity in situ}

A hamburger-like meat product was created as a food matrix following the recommendations of Terra (2005). The ingredients used in the standard formulation of hamburger-like meat were $73 \%$ lean meat, $7 \%$ pork fat, $20 \%$ soy protein and $1.5 \%$ salt.

Initially, to prepare the standard formulation, the chilled beef and pork fat were cut into cubes. Posteriorly, the cubes were ground with the addition of salt in a meat grinder (Bermar Indústria e Comércio ${ }^{\circledR}$ ) with a 6 mm disc. After the process, the hydrated soy protein was added and, after obtaining the homogeneous meat mass, $30 \mathrm{~g}$ of the meat mass were removed and individually wrapped with plastic PVC films (Polyvinyl chloride) and molded in Petri dishes (60 x 15 mm).

The synthetic preservative sodium nitrite $\left(100 \mathrm{~g} / 100 \mathrm{~kg}\right.$ - Duas Rodas Industrial $\left.{ }^{\circledR}\right)$ was added to the meat mass at the end of the process. Then, the hamburger-like meat was coated, using the immersion technique, with the respective chitosan coatings and placed on a sterile support under refrigeration $\left(4^{\circ} \mathrm{C}\right)$ for 7 days, analyzing them on days 2,5 and 7 . 
The following treatments were performed: a) Standard product similar to hamburger without coating; b) Standard product similar to hamburger with chitosan coating; c) Standard product similar to hamburger with chitosan coating incorporated with $\mathrm{CEO}$; d) Standard product similar to hamburger with chitosan coating incorporated with $\mathrm{CEO}$ and $50 \%$ sodium nitrite; and e) Standard product similar to hamburger with $100 \%$ sodium nitrite.

\section{Statistical analysis}

Statistical analysis of the results of antimicrobial activity determination was performed by the analysis of variance with the post-hoc Tukey test $(p<0.05)$. The in situ antimicrobial activity analysis was carried out through the analysis of variance (ANOVA) with the post-hoc Fisher's least significant difference test, LSD $(p<0.05)$.

\section{Results and Discussion}

The clove essential oil was composed of $58 \%$ of the area referring to the eugenol compound, and $41 \%$ of caryophyllene. These results are consistent with those reported by other studies, where eugenol is considered the major compound of clove essential oil, being isolated or in synergism with the other compounds, responsible for the biological potentials of the oil, such as antioxidant, antimicrobial, and antihyperglycemic activity (Radünz et al., 2019; Kalaiselvi et al., 2019; Radünz et al., 2021).

In the disk diffusion method, CEO inhibition halos were detected against E. coli and S. aureus bacteria (Table 1). According to Arora and Kaur (1999), the presence of halos smaller than $7 \mathrm{~mm}$ are considered non-active, they are active when between 7 and $12 \mathrm{~mm}$ and have a satisfactory inhibitory effect when they are more than $12 \mathrm{~mm}$. The CEO inhibition zones were $12 \mathrm{~mm}$ and $16 \mathrm{~mm}$ for E. coli and $S$. aureus, respectively. Therefore, they are considered to have a satisfactory inhibitory effect.

Table 1. Antimicrobial activity of clove essential oil (CEO) by disk diffusion, Minimum Inhibitory Concentration (MIC) and Minimum Bactericidal Concentration (MBC).

\begin{tabular}{llll}
\hline Bacteria & Disk diffusion $(\mathbf{m m}) *$ & MIC $(\mathbf{m g} / \mathbf{m L})$ & MBC $(\mathbf{m g} / \mathbf{m L})$ \\
\hline Escherichia coli & 12 & 3.74 & 374.33 \\
Staphylococcus aureus & 16 & 3.74 & 374.33 \\
\hline
\end{tabular}

*Average of triplicates. Source: Authors.

The results found in this study were comparable to those reported by Santos et al. (2011), which obtained an $11 \mathrm{~mm}$ halo for E. coli and $15.7 \mathrm{~mm}$ for S. aureus. In the study by Pereira et al. (2008), the halos showed a variation of $8 \mathrm{~mm}$ and 12 $\mathrm{mm}$ for E. coli and $10 \mathrm{~mm}$ to $15 \mathrm{~mm}$ for S. aureus. The authors Ghabraie et al. (2016) did not detect the CEO antimicrobial action against E. coli; however, they point out $19.9 \mathrm{~mm}$ inhibition halos for S. aureus.

Table 1 also presents the results for MIC and MBC of CEO, which indicated an inhibitory effect up to a concentration of $3.74 \mathrm{mg} / \mathrm{mL}$ against $E$. coli and $S$. aureus.

The study by Silvestri et al. (2010) also evaluated CEO and found a MIC value of $0.30 \mathrm{mg} / \mathrm{mL}$ for S. aureus, while other authors found values of $0.60 \mathrm{mg} / \mathrm{mL}$ (Beraldo et al., 2013), $0.64 \mathrm{mg} / \mathrm{mL}$ (Ivanovic et al., 2013), 0.50 mg/mL (Santos et al., 2011), $0.80 \mathrm{mg} / \mathrm{mL}$ (Lu et al., 2011) and $0.62 \mathrm{mg} / \mathrm{mL}$ (Xu et al., 2016). Conversely, among the essential oils evaluated by Santos et al. (2017), CEO was the only one that did not inhibit microbial growth in the analyzed concentrations. 
For E. coli, a MIC value of $0.307 \mathrm{mg} / \mathrm{mL}$ was found, which was higher than that assessed by Santos et al. (2011) and Sienkiewicz et al. (2017), where inhibition values of $0.100 \mathrm{mg} / \mathrm{mL}$ were observed. Other studies have found values of 0.600 $\mathrm{mg} / \mathrm{mL}$ (Beraldo et al., 2013), 0.550 mg/mL (Silva et al., 2015) and $0.027 \mathrm{mg} / \mathrm{mL}$ (Gõni et al., 2009).

The CEO antimicrobial action is possibly related to the synergistic effect of the compounds present in essential oil, such as eugenol, and caryophylene, which have hydrophobicity as a characteristic. These compounds can allow the division of lipids present in the bacterial cell membrane, modifying their permeability, promoting cytoplasmic content leakage and resulting in cell death (Devi et al., 2010; Costal et al., 2011; Bakkali et al., 2008).

In the present study, CEO had a bactericidal effect on the concentration of $374.33 \mathrm{mg} / \mathrm{mL}$ for both evaluated bacteria (Table 1). The studies previously mentioned on the CIM results, also assessed MBC of CEO. Beraldo et al. (2013) indicate MBC of $1.8 \mathrm{mg} / \mathrm{mL}$ for $S$. aureus and Silva et al. (2015) obtained MBC from $1 \mathrm{mg} / \mathrm{mL}$, both lower than that found in this trial. Studies by the authors Silva et al. (2015) and Sienkiewicz et al. (2017) discovered the need for 0.100 mg/mL to inhibit E. coli.

The difference in values in the results achieved in the CIM and MBC analyses can be explained by the variations between the evaluation methods employed as well as the solubility of the essential oil or its components (Opalchenova \& Obreshkova, 2003).

In any case, the CEO antimicrobial action was found in this study, even if in higher concentrations when compared to other studies, it attributes the potential to be used as a natural antimicrobial agent in foods.

In the test for antimicrobial activity in the micro-atmosphere, CEO was active against the two bacteria examined (Table 2). The CEO application at a $100 \mu \mathrm{L}$ concentration was able to promote reductions of up to $76 \%$ against the tested bacteria.

Table 2. Antimicrobial activity of clove essential oil (CEO) in a micro-atmosphere against Escherichia coli and Staphylococcus aureus.

\begin{tabular}{llll}
\hline Essential oil & Volume $(\boldsymbol{\mu L})$ & Escherichia coli $(\%) *$ & Staphylococcus aureus $(\%) *$ \\
\hline Clove & 12.5 & 15.8 & 18.9 \\
25 & 51.7 & 31 \\
50 & 61.7 & 34 \\
& 70 & 76 \\
\hline
\end{tabular}

* Percentage reduction in cell count (CFU) compared to a control containing sterile distilled water. Source: Authors.

The lower volume of essential oil added $(12.5 \mu \mathrm{L})$ also resulted in decreases between $15.8 \%$ and $18.9 \%$ for E. coli and S. aureus, respectively. These results indicate that the medium, where the essential oil is applied, directly influences its diffusion and propagation.

The authors Ghabraie et al. (2016) explain that the nonpolar characteristic of essential oils hinders their propagation in water-based media, since the antimicrobial constituents of essential oils come into contact with the microbial cell through volatilization, in the micro-atmosphere.

In the Total Coliforms analysis and at $45{ }^{\circ} \mathrm{C}$ (Thermotolerants), it was possible to observe that in all formulations, evaluated over 7 days of refrigerated storage, with the presence of chitosan coating with and without the incorporation of CEO, indicated counts <0.3 MPN / g during the storage period, remaining constant. Concomitantly, there was a reduction in the initial count of $0.94 \mathrm{MPN} / \mathrm{g}$ of Total Coliforms in the control formulation. 
According to the standards required by Resolution (Resolução de Diretoria Colegiada, RDC) number 12/2001 of the National Health Surveillance Agency (ANVISA), raw, chilled or frozen meat products must have a tolerance of 5x10 ${ }^{3}$ MPN/g for Coliforms at $45{ }^{\circ} \mathrm{C}$ (Brazil, 2001). Thus, the obtained results indicated that the analyzed hamburger-like meat product was within the standards established by the current legislation and acceptable for consumption.

The results point to the efficiency of the chitosan coating added with essential oil as a natural antimicrobial in foods, as it can promote the control of microbial proliferation that could allow the multiplication of pathogenic microorganisms. Similar behavior was observed in coatings formed by chitosan (2\%) and gelatin (6\%) incorporated with $0.75 \%$ CEO, which reduced the counts of decaying bacteria in cod fillets (Gadus morhua) for 11 days of refrigerated storage (Gómez-Estaca et al., 2010).

The averages of the Coagulase-Positive Staphylococcus quantifications present in the formulation of hamburger-like meat product submitted to different treatments can be seen in Table 3.

Table 3. Averages of Coagulase-Positive Staphylococcus quantifications in hamburger-like meat product submitted to different treatments stored at $4{ }^{\circ} \mathrm{C}$ for up to 7 days.

\begin{tabular}{|c|c|c|c|c|}
\hline \multirow[t]{3}{*}{ Treatment } & \multicolumn{4}{|c|}{ Coagulase-Positive Staphylococcus (Log UFC g g $^{-1}$ ) } \\
\hline & Time 0 & Time 1 & Time 2 & Time 3 \\
\hline & (0 days) & (2 days) & (5 days) & (7 days) \\
\hline T1 & $4.35^{\mathrm{aA}}$ & - & - & - \\
\hline $\mathbf{T} 2$ & - & $1.13^{\mathrm{bA}}$ & $0.00^{\mathrm{bB}}$ & $0.00^{\mathrm{bB}}$ \\
\hline T3 & - & $1.13^{\mathrm{bA}}$ & $0.00^{\mathrm{bB}}$ & $0.00^{\mathrm{bB}}$ \\
\hline T4 & - & $0.00^{\mathrm{bA}}$ & $0.00^{\mathrm{bB}}$ & $0.00^{\mathrm{bB}}$ \\
\hline T5 & - & $0.00^{\mathrm{bA}}$ & $0.00^{\mathrm{bB}}$ & $0.00^{\mathrm{bB}}$ \\
\hline
\end{tabular}

T1 - Control (Standard product similar to hamburger without coating); T2 - Standard product similar to hamburger with chitosan coating; T3 - Standard product similar to hamburger with chitosan coating incorporated with CEO; T4 - Standard product similar to hamburger with chitosan coating incorporated with CEO and 50\% nitrite; T5 - Standard product similar to hamburger with $100 \%$ sodium nitrite. Different lower-case letters in the line or different upper-case letters in the column indicate significant differences (Fisher $-p<0.05$ ). Source: Authors.

For the Coagulase-Positive Staphylococcus microorganism, treatment T3, with the coating application, significantly reduced $(p<0.05)$ the counts from 4.35 to $1.33 \log$ CFU. $\mathrm{g}^{-1}$ compared to the control treatment (T1), remaining lower until the last analyzed time. However, there was no significant reduction $(p>0.05)$ in the number of viable cells between times after the second day of storage (Time 1). Hamburger-like meat made with chitosan coating met the requirements established by legislation for Coagulase-Positive Staphylococcus with counts below 5x10³ MPN/g (Brazil, 2001).

The authors Asbahani et al. (2015) suggest that the antimicrobial activity of essential oils is related to their hydrophobic structure, considering the phospholipids of the cytoplasmic membrane as their main cellular targets, as it would facilitate their diffusion through the membrane structure. This accumulation alters the density of the cell membrane and, consequently, the permeability, causing the gradual loss of vital cellular components to the external environment (Burt, 2004; Rai et al., 2017).

Brazilian legislation recommends the use of potassium nitrite and sodium nitrate at levels of up to $0.015 \mathrm{~g} / 100 \mathrm{~g}$ and $0.03 \mathrm{~g} / 100 \mathrm{~g}$ in meat products, respectively (Brasil, 2019). The in situ analysis showed potential by incorporating $1 \%$ of the CEO to the chitosan coating in meat products similar to hamburgers. Thus, the total or partial replacement of the preservative by $\mathrm{CEO}$ becomes a viable alternative to a natural preservative, since nitrite can form nitrosamines that may have carcinogenic 
potential.

\section{Conclusion}

The clove essential oil was mainly composed of eugenol, and through in vitro tests, clove essential oil showed a satisfactory effect against the tested bacteria. In the evaluated hamburger-like meat product, the chitosan coatings incorporated with the clove essential oil, as well as its antimicrobial activity in vitro, were able to promote the control of the microbial proliferation of Total Coliforms, Coliforms at $45^{\circ} \mathrm{C}$ and Coagulase-Positive Staphylococcus throughout 7 days of refrigerated storage, making it a promising alternative to control the development of microorganisms of importance in foods.

\section{References}

Appendini, P. \& Hotchkiss, J. H. (2002). Review of antimicrobial food packaging. Innovative Food Science \& Emerging Technologies, 3, $113-126$.

Arora, D. S. \& Kaur, J. (1999). Antimicrobial activity of spices. Internation. Journal of Antimicrobials Agents, 12, $257-262$.

Asbahani, a El, Miladi, K., Badri, W., Sala, M., Addi, E. H. A., Casabianca, H. \& Elaissari, A. (2015). Essential oils: From extraction to encapsulation. International Journal of Pharmaceutics, 483, 220-243.

Bakkali, F., Averbeck, S. \& Idaomar, M. (2008). Biological effects of essential oils - A review. Food and Chemical Toxicology, 46, 446-475.

Beraldo, C., Daneluzzi, N. S., Scanavacca, J., Doyama, J. T., Fernandes Júnior, A., \& Moritz, C. M. F. (2013). Eficiência de óleos essenciais de canela e cravo-da-índia como sanitizantes na indústria de alimentos. Pesquisa Agropecuária Tropical, 43, 436-440.

Brasil, Agência Nacional de Vigilância Sanitária, Resolução, Resolução da Diretoria Colegiada $N^{\circ} 272$, de 14 de março de 2019 , Estabelece os aditivos alimentares autorizados para uso em carnes e produtos cárneos. Diário Oficial da União, 52 (1), 194.

Brasil, Agência Nacional De Vigilância Sanitária, Resolução, Resolução da Diretoria Colegiada No 12 , de 2 de janeiro de 2001, Regulamento técnico sobre padrões microbiológico para alimentos. Diário Oficial da União, Seção 1.

Burt, S. (2004). Essential oils: their antibacterial properties and potential applications in foods — a review. International Journal of Food Microbiology, 94, 223-253.

Cabral, I. S. R., Prado, A., Bezerra, R. M. N., Alencar, S. M., Ikegaki, M. \& Rosalen, P. L. (2009). Composição fenólica, atividade antibacteriana e antioxidante da própolis vermelha brasileira. Química Nova, 32, 1523-1527.

Calo, J. R., Crandall, P. G., O’Bryan, C. A. \& Ricke, S. C. (2015). Essential Oils as Antimicrobials in Food Systems- A Review. Food Control, 54, 111-119.

Clinical and Laboratory Standars Institute. M02-A11 performance standards for antimicrobial disk susceptibility tests (2012). Wayne, Pennsylvania, USA, 950 .

Coma, V. (2008). Bioactive packaging technologies for extended shelf life of meat-based products. Meat Science, 78, 90-103.

Costa, A. R., Amaral, M. F. Z., Martins, P., Paula, J. A., Fiuza, T., Tresvenzol, L. M., \& Bara, M. T. (20110. Ação do óleo essencial de Syzygium aromaticum (L.) Merr. \& L. M. Perry sobre as hifas de alguns fungos fitopatogênicos. Revista Brasileira de Plantas Medicinais, 13, 240-245.

Dannenberg, G. da S., Funck, G. D., Mattei, F. J., Silva, W. P. da, \& Fiorentini Â. M. (2016). Antimicrobial and antioxidant activity of essential oil from pink pepper tree (Schinus terebinthifolius Raddi) in vitro and in cheese experimentally contaminated with Listeria monocytogenes. Food Science and Emerging Technologies, 36, 120-127.

Devi, K. P., Nisha, S. A., Sakthivel, R., \& Pandian, S. K. (2010). Eugenol (an essential oil of clove) acts as an antibacterial agent against Salmonella typhi by disrupting the cellular membrane. Journal of Ethnopharmacology, 130, 107-115.

Downes, F. P., \& Ito, H. (2001). Compendium of methods for the microbiological examination of foods. (4th ed.). Washington: American Public Health Association.

Ghabraie, M., Vu, K. D., Tata, L., Salmieri, S., \& Lacroix, M. (2016). Antimicrobial effect of essential oils in combinations against five bacteria and their effect on sensorial quality of ground meat. LWT - Food Science and Technology, 66, 332-339.

Gómez-estaca, J., López De Lacey, A., López-Caballero, M. E., Gómez-Guillén, M. C., \& Montero, P. (2010). Biodegradable gelatin-chitosan films incorporated with essential oils as antimicrobial agents for fish preservation. Food Microbiology, 27, 889-896.

Goñi, P., López, P., Sánchez, C., Gómez-Lus, R., Becerril, R., \& Nerín, C. (2009). Antimicrobial activity in the vapour phase of a combination of cinnamon and clove essential oils. Food Chemistry, 116, 982-989.

Hosseini, S. F., Rezaei, M., Zandi, M. \& Farahmandghavi, F. (2015). Bio-based composite edible films contraining Origanum vulgare L. essential oil. Industrial Crops and Products, 67, 403-413.

Kurita, K. (2006). Chitin and Chitosan: Functional Biopolymers from Marine Crustaceans. Marine Biotechnology, 8, $203-226$. 
Lu, F., Ding, Y., Ye, X., \& Ding, Y. (2011). Antibacterial Effect of Cinnamon Oil Combined with Thyme or Clove Oil. Agricultural Sciences in China, 10, 1482-1487.

Macwan, S. R., Dabhi, B. K., Aparnathi, K. D., \& Prajapati, J. B. (2016). Essential Oils of Herbs and Spices: Their Antimicrobial Activity and Application in Preservation of Food. International Journal of Current Microbiology and Applied Sciences, 5, 885-901.

Moradi, M., Tajik, H., Rohani, S. M. R., \& Oromiehie, A. R. (2011). Efectiveness of Zataria multiflora Boiss essential oil and grape seed extract impregnated chitosan film on ready-to-eat mortadella-type sausages during refrigerated storage. Journal of the Science of Food and Agriculture, 91, $2850-2857$.

Otoni, C. G., Espitia, P. J. P., Avena-Bustillos, R. J., \& McHugh, T. H. (2016). Trends in antimicrobial food packaging systems: Emitting sachets and absorbent pads. Food Research International, 83, 60-73.

Opalchenova, G. \& Obreshkova, D. (2003). Comparative studies on the activity of basil—an essential oil from Ocimum basilicum L.—against multidrug resistant clinical isolates of the genera Staphylococcus, Enterococcus and Pseudomonas by using different test methods. Journal of Microbiological Methods, $54,105-110$.

Organização Mundial da Saúde - OMS (2020). Comunicado de prensa del Centro Internacional de Investigaciones sobre el Cáncer sobre el Cáncer evalúa el consumo de la carne roja y de la carne processada. http://www.who.int/mediacentre/news/releases/2015/cancer-red-meat/es/

Pereira, A. de A., Cardoso, M. das G., Abreu, L. R. de, Morais, A. R. de, Guimarães, L. G. de L. \& Salgado, A. P. S. P. (2008). Chemical characterization and inhibitory effect of essential oils on the growth of Staphylococcus aureus and Escherichia coli. Ciência e Agrotecnologia, 32, 887-893.

Radünz, M., Camargo, T. M., Hackbart, H. C., Alves, P. I. C., Radünz, A. L., Gandra, E. A., \& Zavareze, E. R. (2021). Chemical composition and in vitro antioxidant and antihyperglycemic activities of clove, thyme, oregano, and sweet orange essential oils. LWT-Food Science and Technology, 138, 257-262.

Radünz, M., da Trindade, M. L. M., Camargo, T. M., Radünz, A. L., Borges, C. D., Gandra, E. A., \& Helbig, E. (2019). Antimicrobial and antioxidant activity of unencapsulated and encapsulated clove (Syzygium aromaticum, L.) essential oil. Food Chemistry, 276, $180-186$.

Rai, M., Paralikar, P., Jogee, P., Agarkar, G., Ingle, A. P., Derita, M. \& Zacchino, S. (2017). Synergistic antimicrobial potential of essential oils in combination with nanoparticles: Emerging trends and future perspectives. International Journal of Pharmaceutics, 519, 67-78.

Santos, J. C., Filho, C. D. C., Barros, T. F. \& Guimarães, A. G. (2011). In vitro antimicrobial activity of essential oils from oregano, garlic, clove and lemon against pathogenic bacteria isolated from Anomalocardia brasiliana. Semina: Ciências Agrárias, Londrina, 32, $1557-1564$.

Santos, C. H. S., Piccoli, R. H. \& Tebaldi, V. M. R. (2017). Atividade antimicrobiana de óleos essenciais e compostos isolados frente aos agentes patogênicos de origem clínica e alimentar. Revista Instituto Adolfo Lutz, São Paulo, 76, 1719.

Scopel, R., Falcão, M. A., Lucas, A. M. Almeida, R. N., Gandolfi, P. H. K., Cassel, E. \& Vargas, R. M. F. (2014). Supercritical fluid extraction from Syzygium aromaticum buds: Phase equilibrium, mathematical modeling and antimicrobial activity. Journal of Supercriticial Fluids, 93, 223-230.

Silva, A. A. da, Anjos, M. M. dos, Ruiz, S. P., Panice, L. B., Mikcha, J. M. G., Junior, M. M. \& Filho, B. A. de A. (2015). Avaliação da atividade óleos essenciais de Thimus vulgaris (Tomilho), Syzygium aromaticum (Cravo-da-india) E Rosmarinus officinalis (Alecrim) e dos conservantes benzoato de sódio e sorbato de potássio em Escherichia coli E Staphylococcus aureus. Boletim do Centro de Pesquisa de Processamento de Alimentos, 33.

Silvestri, J. D. F., Paroul, N., Czyewski, E., Lerin, L., Rotava, I., Cansian, R. L., Mossi, A., Toniazzo, G., Oliveira, D. \& Treiche, H. (2010). Perfil da composição química e atividades antibacteriana e antioxidante do óleo essencial do cravo-da-índia (Eugenia caryophyllata Thunb.). Revista Ceres, 57, 589594.

Sindelar, J. J. \& Milkowski, A. L. (2011). Sodium nitrite in processed meat and poultry meats: a review of security and examining the risk/benefits of its use. American Meat Science Association, 3.

Terra, N. N. (2005). Apontamentos em Tecnologia de Carnes. São Leopoldo: Editora da Universidade do Vale do Rio dos Sinos.

Xu, J.-G., Liu, T., Hu, Q.-P. \& Cao, X.-M. (2016). Chemical Composition, Antibacterial Properties and Mechanism of Action of Essential Oil from Clove Buds against Staphylococcus aureus. Molecules, 21, 1194. 